\title{
Responsabilidade Civil dos Ministros de Estado
}

\section{Carlindo Hugueney}

Q

UANDO no século XIII os barões impuseram a João Sem Terra a assinatura de um documento escrito, a Magna Carta, no qual ficava estabelecido que o Chefe de Estado, entre outros fatos, não podia lançar impostos e taxas sem prévia aquiescência dos súditos, estava, em principio, atingido, em sua maior amplitude, o contrôle das finanças públicas.

Com efeito, na época, o rei para prover os gastos de sua côrte, tinha necfssidade de, prèviamente, aprovisionar o seu real bôlso da quantia indispensável, o que fazia à discrição. Limitado êsse aprovisionamento, pela nécessidade da prévia aquiescência dos governados, estariam, por via de conseqüência, controlados os gastos do rei.

Mas é bem de ver que tôdas as vêzes em que se estabelece uma norma que visa a reprimir determinado abuso sempre acontece surgirem processos em razão dos quais se obtém a anulação, ou pelo menos a mitigação, do alcance do contrôle.

No campo das finanças públicas, vários fatos vieram a posteriori modificar quase que radicalmente aquêle sistema de' contrôle, tornando-o ineficaz, embora até hoje, sete séculos após, continuemos aferrados àquela tradição histórica como se, ao cabo de contas, tivesse grande alcance prático a medida.

Na réalidade, porém, desde que surgiu e se alargou o sistema monetário moderno, à luz do qual não é mais necessário o lançamento de tributos para ericher a arca do tesouro dos suprimentos de fundos necessários à manutenção das necessidades do Estado, já que êste detém o monopólio da fabricação do dinheiro, obsoleto ficou o contrôle da receita através da prévia aprovação dos tributos. Adema:s, na ciência das finanças evoluiu-se do critério individualista de se pautar os gastos em função da receita para entender-se qué esta é que deve ser orçada de acôrdo com os gastos fixados cono nécessários aos fins do Estado.

Se, pois, o cidadão, visando a não desfalcar seu patrimônio, nega aos dirigentes, através de seus representantes, o direito de lançar novos tributos, nem por isso deixa de ficar mais empobrecido, quando o Estado, em contrapartida, para suprir a falta de renda necessária à despesa pública, coloca em circulação maior quantidade de papel-moeda, que reduz proporcionalmente o valor aquisitivo do meio circulante. 
Dai, no mundo moderno haver surgido a idéia de que também era necessário controlar as atividades do poder dirigente, exigindo-lhe, também, a prévia aprovação de seu orçamento de despesa, embora por outras formas se possa explicar o fato.

Pelo simples enunciado dessas razões, evidencia-se que o contrôle do poder dirigente seria muito mais eficaz através do orçamento da despesa do que da receita.

Todavia, não é êsse o entendimento comum. De fato, se o Govêrno, pelo menos entre nós, deseja aumentar as necessidades do Tesouro e solicita novos tributos, o que se verifica são, em realidade, vivos débates nas tribunas do Parlamento, como na imprensa falada ou escrita, não ficando infenso a êle o cidadão que, não raro, vai até a ameaça de recorrer ao contrôle judicial quando vislumbra, pelo menos na sua concepção, alguma eiva de inconstitucionalidade.

Diga-se, contudo, que enquanto isso, apenas na maior parte das vêzes a titulo noticioso, a imprensa transcreve o Diário Oficial, dizendo do aumento do meio circulante...

Por outro lado, quem se dedica à leitura do Diário do Congresso, o que observa é, por que não dizer, um açodamento do Legislativo em conceder ao Executivo não aquilo que julgou indispensável e pede e, sim, muito mais do que pede.

Assim, neste particular, o que se verifica é um contrôle às avessas : o Legislativo concéde ao Executivo aquilo que pede e o que não pede, através de um orçamento de despesa sempre majorado, nunca diminuido, a que sempre se somam vultosos créditos adicionais.

Dai surgir modernamente um fenômeno digno de realce: é o Exécutivo que se vê na contingência de lançar mãos de meios para coibir a liberalidade do órgão de contrôle, estabelecéndo «planos de economia» que visam a - livrá-lo da liberalidade do legislador, quando lícito seria esperar que o contrário se verificasse, se o contrôle sôbre o orçamento da despe'sa realmente existisse.

Assim, embora perfunctòriamente, podemos ver que é grandemente deficiente o contrôle que exerce o povo sôbre os dirigentes através da prévia aprovação dos orçamentos da receita e da despesa.

Restaria, pois, a largo pano, indicar como se processa, a posteriori, o contrôle através da apreciação da execução orçamentária.

Há um vêzo, muito comum, de se procurar, por uma concepção simplista, atribuir ao dirigente todos os males.

Assim é que quando um trem descarrilha, a primeira idéia que se tem é de se descarregar nas costas do maquinista todo o pêso da responsabilidade como se, ao cabo de contas, não estivesse sob o seu contrôle um sistema 
complexo de máquinas e coisas e como não bastasse o simples afrouxamento de um parafuso do trilho para que todo êsse complexo de coisas fugisse ao seu comando.

No que tange às finanças públicas, o mesmo fenômeno se verifica, pôsto que ainda permanecemos adstritos à concepção que nos veio da época de João Sem Terra de que o contrôle deve ser exercido contra o Chefe de Estado.

Poucos, porém, se dão conta de que, se naquela ocasião o dinheiro público era canalizado para o real bôlso do dirigente que dêle dispunha ao seu talante, hoje, ao reverso, o organismo do Estado é uma máquina complexa, movida por inúmeras engrenagens, e que, na maior parte ou na quase totalidade, os gastos se processam à revclia do Supremo dirigente.

Quem se der ao trabalho de ler os relatórios do Tribunal-de Contas da União sôbre as contas do Presidente da República verificará um sem número de irregularidades: despesas sem crédito, despesas além dos créditos, despesas pagas ilegalmente, despesas não submetidas a registros. De tal porte as irregularidades, e isso é estarrecedor, que o montante delas supera de muito àquelas que se processaram regularmente.

Maj, como bem ponderou o ilustrado Ministro Joaquim Coutinho em se'u fundamentado voto na sessão de 29 de abril último, tais irregularidades não podem ser levadas a débito do Presidente da República pôsto que os quarenta anos de serviço daquele conspícuo ministro nos mais altos postos da administração pública lhe ensinaram - as mesmas não chegam sequer ao conhecimento do Supremo magistrado, visto que se originam de atos dos mais variados agentes públicos. Outra não é aliás a opinião do ilustrado Diepitado Hamilton PRAdo, Relator, na Comissão de Orçamento da Câmara, das contas do Govêrno, exercício de 1958 (D.C.N. - S.I., pág. 6.822 $-18-7-59)$. lidade.

Isso é um corolário lógico do regime democrático, do sistema de lega-

Num pais que defende o postulado de que todos são iguais perante a lei e que cada agente do poder público enfeixa em suas mãos certa soma de poder que a lei lhe atribui, não é lícito raciocinar-se nas mesmas bases com que se concebia o país sujeito ao guante de máximas como «l'Etat c'est moi».

Se, naquela época, quem dirigia encarnava o próprio Estado, lícito era atribuir-lhe as re'sponsabilidades decorrentes de quaisquer irregularidades. Hoje, ao reverso, quando todos são iguais perante a lei, e cada um detém uma soma de direitos e atribuições próprios, nada mais lógico que a cada um dêles se adjudique a responsabilidade decorrente da falta da exação no cumprimento do seu dever.

Não é isso, contudo, o que se observa. Estamos, ainda, como se disse, adstritos às idéias do regime absolutista, com arremedos de principios démocráticos.

Com efeito. Em que pese a circunstância de a Constituição determinar que todos os responsáveis pela guarda ou emprêgo de bens ou dinheiros 
públicos deve ter sua gestão apreciada (Const., art. 77 , II), ainda continuamos aferrados ao primitivismo histórico, emprestando às contas do Presidente da República alcance qué evidentemente não tem.

Assim é que muitos pensam que julgadas boas as contas do Presidente da República ipso facto liberados ficam, também, os seus auxiliares, quando licito era esperar outro razoável entendimento.

Por essa forma, embora, como se disse, determine a Constituição que todos devam prestar contas; embora o Chefe de Estado esteja também obrigado a essa formalidade (Const., art. 77, § 4\%); embora determine também a Constituição, como seria lógico em um regime democrático, que os Ministros de Estado respondam por todos os atos que expedirem (Const., art. 93), ainda assim se entende que os Ministros de Estado não estão sujeitos à prestação de contas perante o Tribunal de Contas, isso por fôrça do art. 876 do R.G.C.P.

Entendemos ser isso uma aberração juridica. Se certo é que todos devem prestar contas, se é certo que nem o Chefe de Estado é isento dessa obrigação, razoável seria compreender que dessa obrigação não poderiam fugir os Ministros de Estado. Se certo é, por outro lado, que a Constituição não dá ao Ministro de Estado direito à jurisdição especial no exame de suas contas, salvo nos atos conexos com os do Presidente da República (Const., art. 92), lógico seria inferír que estão êles sujeitos ao contrôle geral exercido pelo Tribunal de Contas.

Observe-se' a respeito que não é outro o entendimento do legislador ao estabelecer expressamente a obrigação de os mesmos prestarem contas em casos que regula (Lei $\mathrm{n}^{\circ} 830-49$, art. $63, \S 1^{\circ}$ ).

O Tribunal de Contas, porém, permanece em principio adstrito ao velho preceito do art. 876 do R.G.C.P., fulcro de muitos males em nosso regime democrático pôsto que alguns Ministros usam e abusam do direito de não prestar contas, colocando-se como se fôssem, ao cabo de contas, autoridade's supra-estatais, não sujeitas aos contrôles estabelecidos para todos os cidadãos da república, entre os quais o próprio Presidente.

Nem se diga, como querem outros, que os Ministros de Estado, por estarem sujeitos à lei de responsabilidade, deve'm responder perante o Parlamento e, portanto, não ficam sujeitos à prestação de contas. O Presidente da República, também, está sujeito ao impeachment e nem por isso fica desobrigado de prestar suas contas, pois as duas coisas são diversas.

Por igual, prevê a lei (Estatuto, art. 196) que o funcionário público está sujeito às responsabilidades penal, administrativa e civil. Respondem penalmente pelas ações ou omissões que praticarem no exercício ou em razão do cargo; administrativamente ficam sujeitos a sanções que vão até a perda do cargo com inabilitação para exercer outro (art. 209), ficando, ainda, civilmente obrigados a reparar o dano à Fazenda Nacional (art. 197).

São responsabilidades que se somam, uma não excluindo a outra.

O crime dé responsabilidade é, mutatis mutandis, por motivos óbvios, Sćnção que corresponde à pena de caráter administrativo imposta aos funcionários em geral. 
Assim, esquemàticamente, podemos ver que o Presidente da República, os Ministros e funcionários em geral estão sujeitos à sanção penal; os dois primeiros ficam sujeitos à lei de responsabilidade, o que corresponde às sanções administrativas impostas ao funcionário em geral.

No que tange à responsabilidade civil, o Presidente da República presta, anualmente, suas contas ao Congresso Nacional (Const., art. $77, \quad 4^{\circ}$ ); os funcionários em geral ficam sob a jurisdição do Tribunal de Contas. Os Ministros de Estado, porém, permanecem fora do campo de contrôle de qualquer órgão: nem prestam contas ao Parlamento das suas gestões como Chefes de grandes Departamentos, nem se incluem na categoria geral sujeita ao contrôle do Tribunal de Contas. Isso, como se disse, em face de entender-se, ainda hoje, que continua em vigor o art. 876 do R.G.C.P.

Urge, portanto, que se defina convenientemente a responsabilidade civil dos Ministros de Estado nos atos que expedirem como chefes de grandes setores da Administração pública, pôsto que o regime democrático é incompativel com o sistema de irresponsabilidade. 